\title{
Expression of avrPphB, an Avirulence Gene from Pseudomonas syringae pv. phaseolicola, and the Delivery of Signals Causing the Hypersensitive Reaction in Bean
}

\author{
Nakul Puri, ${ }^{1}$ Carol Jenner, ${ }^{1}$ Mark Bennett, ${ }^{1}$ Ruth Stewart, ${ }^{1}$ John Mansfield, ${ }^{1}$ Nigel Lyons, ${ }^{2}$ and John \\ Taylor $^{2}$ \\ ${ }^{1}$ Department of Biological Sciences, Wye College, University of London, Ashford, Kent, TN25 5AH U.K.; \\ ${ }^{2}$ Horticulture Research International, Wellesbourne, Warwick, CV35 9EP U.K. \\ Received 16 September 1996. Accepted 27 November 1996.
}

Protein production encoded by the avirulence gene avrPhB from Pseudomonas syringae pv. phaseolicola was examined. Incorporation of $\left[{ }^{35} \mathrm{~S}\right]$-labeled methionine into the AvrPphB protein indicated processing of the fulllength peptide in Escherichia coli to give a major $28-\mathrm{kDa}$ product. The $28-\mathrm{kDa}$ native peptide was isolated from $E$. coli following over-expression of $a v r P p h B$ and found not to elicit the hypersensitive response (HR) after infiltration into bean leaves. Antiserum raised to the $28-\mathrm{kDa}$ peptide allowed expression of $a v r P p h B$ and processing of AvrPphB protein to be examined in $P$. syringae pv. phaseolicola; immunoreactive peptides of both 35 and 28-kDa were detected in races 3 and 4 (which contain $a v r P p h B$ ) only after induction in minimal medium $+10 \mathrm{mM}$ sucrose. Antiserum raised to a synthetic peptide, derived from the sequence of the 62 amino acids found to be cleaved from the full-length AvrPphB protein, revealed the accumulation of peptides corresponding to the smaller cleavage products, in both $E$. coli and $P$. syringae pv. phaseolicola. Biochemical localization experiments showed that all AvrPphB peptides were cytoplasmic in $P$. syringae pv. phaseolicola. No AvrPphB peptides were produced in a $h r p L$ mutant unless expression of the gene was directed by a strong vector promoter; induction kinetics similar to wild type were observed in a $h r p Y^{-}$strain, although it also failed to cause a confluent HR. Growth of $P$. syringae pv. phaseolicola under inducing conditions removed the requirement for rifampicin-sensitive mRNA synthesis by bacteria to allow HR development (the induction time) in bean and lettuce leaves. Constitutive expression of $h r p L$ reduced but did not remove the induction time. Expression of the hrp gene cluster of $P$. syringae pv. phaseolicola from plasmid pPPY 430 in $E$. coli enabled phenotypic expression of avrPphE (also carried by pPPY430) and avrPphB (if overexpressed from pPPY3031). Despite constitutive expression of the $h r p$ and $a v r$ genes in $E$. coli, a protein synthesis dependent induction time was still required for development of the HR in bean genotypes with matching resistance genes. The significance of processing for the function

Corresponding author: J. Mansfield; E-mail: J.Mansfield@wye.ac.uk of AvrPphB peptides and the delivery of elicitors of the HR are discussed.

Additional keywords: disease resistance, halo-blight, signalling.

Race-specific resistance to halo-blight in bean (Phaseolus vulgaris L.) is based on gene-for-gene interactions involving five genes for resistance $(R)$ in the host and five matching genes for avirulence ( $a v r$ ) in the pathogen, Pseudomonas syringae pv. phaseolicola (Jenner et al. 1991; Mansfield et al. 1996). Three $a v r$ genes, those matching $R 1, R 2$, and $R 3$, have been cloned and sequenced (Jenner et al. 1991; Mansfield et al. 1994, 1996). Originally described as avrPph3 (Jenner et al. 1991), the full designation of the $a v r$ gene matching $R 3$ is now avrPphB1.R3, indicating that it was the second $a v r$ gene to be cloned from $P$. syringae pv. phaseolicola $(B)$, the first allele of that gene ( 1 ) and that it matches $R 3$ from $P$. vulgaris (Vivian and Mansfield 1993). The gene will subsequently be termed $a v r P p h B$. Identical alleles of $a v r P p h B$ occur in races 3 and 4 of $P$. syringae pv. phaseolicola which cause a characteristically rapid hypersensitive reaction (HR) in bean cultivars with R3 (Jenner et al. 1991; Mansfield et al. 1994). No DNA sequences hybridizing to probes for $a v r P p h B$ are found in strains of $P$. syringae pv. phaseolicola which are virulent on $R 3$ cultivars, indicating that $a v r P p h B$ is not generally required for pathogenicity in the halo-blight bacterium. The presence of avrPphB also confers avirulence to pea, soybean, and Arabidopsis (Fillingham et al. 1992; Pirhonen et al. 1996; Simonich and Innes 1995). In Arabidopsis, the matching $R$ gene, RPS5 has been mapped to chromosome 1 (Simonich and Innes 1995). Determination of specificity in such a wide range of plants has now been reported for other $a v r$ genes from pathovars of $P$. syringae notably avrB, avrRpm1, and its homolog avrPpiA1.R2 (Dangl et al. 1992; Fillingham et al. 1992; Grant et al. 1995; Vivian et al. 1997).

Although more than 50 alleles of avr genes have been cloned from pathovars of Pseudomonas and Xanthomonas, the functions of their encoded proteins, which are typically predicted to be hydrophilic and to lack signal sequences, remains virtually unknown (Dangl 1994; Vivian et al. 1997). A few 
genes have been ascribed a role in basic pathogenicity as well as avirulence, e.g., avrE and avrRpml from P. syringae pvs. tomato and maculicola, respectively (Lorang et al. 1995; Ritter and Dangl 1995). The avrD gene from P. syringae pv. glycinea is thought to encode an enzyme involved in the synthesis of syringolides which are secreted from both $P$. syringae and Escherichia coli and elicit an $R$ gene-specific in soybean (Keen 1992; Keen et al. 1990; Midlands et al 1993; Smith et al. 1993). In contrast to $a v r D$, overexpression of several other avr genes from $P$. syringae does not allow $E$. coli to elicit the HR or to secrete elicitors (Keen 1992).

All of the avirulence genes cloned from $P$. syringae contain motifs within their promoters indicating probable regulation by $h r p L$ from within the cluster of homologous $h r p$ genes found in pathovars of the species ( Innes et al. 1993; Mansfield et al. 1994; Xiao et al. 1994; Vivian et al. 1997). Evidence is accumulating for the invovement of other hrp genes in a specialized protein secretion system which, in modified forms, is common not only to plant but also animal pathogens (Bonas 1994; Huang et al. 1995; Van Gijsegem et al. 1995). In recent experiments described by Pirhonen et al. (1996), strains of $E$. coli have been found to be able to elicit a cultivarspecific HR in Arabidopsis and soybean if they harbor pHIR11 which contains hrmA and the entire cluster of hrp genes from $P$. syringae pv. syringae, and also plasmids allowing over-expression of $h r p L$ and certain avirulence genes. Pirhonen et al. (1996) point out that the hrp-dependent secretion system which appears to be functional in E. coli may allow delivery of the protein products of $a v r$ genes directly into plant cells, where they may themselves act as elicitors of the HR. Support for a direct role for the Avr proteins also comes from the finding that expression of $a v r B$ in plant cells can lead to the HR (Gopalan et al. 1996). Alternatively, the encoded Avr proteins may have a role in the biosynthesis of

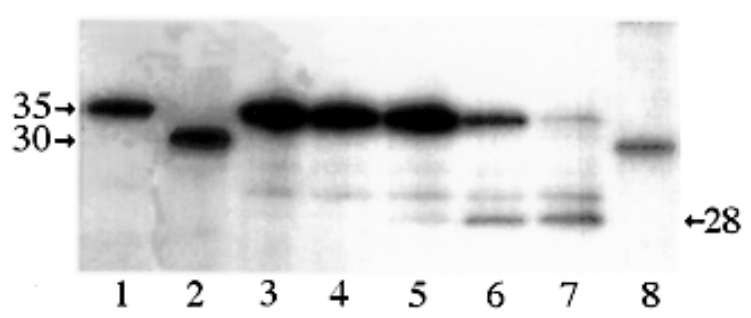

Fig. 1. Synthesis and rapid processing of AvrPphB peptides in Escherichia coli. Proteins synthesized after T7 polymerase regulated expression of $\operatorname{avrPphB}$ were labeled with $\left[{ }^{35} \mathrm{~S}\right]-$ methionine. Samples for lanes were taken; 1 , immediately after addition of label and 3 , after 1 min of incubation (pulse), before the addition of unlabeled methionine (chase) and sampling after 1, 10, 30, and 60 min (lanes 4, 5, 6, and 7). Lanes 2 and 8 are 30-kDa markers. Peptides were separated by SDSPAGE before autoradiography. Sizes of peptides are marked in kDa. elicitors which (unlike the syringolides) require hrp functions for their delivery. In both scenarios, knowledge of the structure and properties of the Avr proteins becomes of fundamental importance for the understanding of gene-for-gene interactions.

In this article we describe analysis of expression of the protein encoded by $a v r P p h B$ and the finding that AvrPphB is processed in both $E$. coli and $P$. syringae pv. phaseolicola. Phenotypic expression of both $a v r P p h B$ and $a v r P p h E$ was achieved in E. coli using the cluster of hrp genes cloned from $P$. syringae pv. phaseolicola. Evidence is presented that both $E$. coli and $P$. syringae pv. phaseolicola require construction of a delivery system in the plant to allow transfer of elicitors of the HR.

\section{RESULTS}

\section{Pulse-chase experiments reveal processing of AvrPphB in $E$. coli.}

To confirm expression of protein from the $a v r P p h B$ gene, the predicted open reading frame (ORF) was cloned into vectors for expression by $\mathrm{T} 7$ polymerase using the T7-n plasmids developed by Tabor and Richardson (1985). In the first experiments incorporation of $\left[{ }^{35} \mathrm{~S}\right]$-labeled methionine was examined 15 min after addition of label. Two major labeled peptides at $35-$ and $28-\mathrm{kDa}$ were detected. A pulse-chase experiment, involving sampling $0,1,10,30$, and $60 \mathrm{~min}$ after chasing with unlabeled methionine, indicated that the $35-\mathrm{kDa}$ peptide was rapidly processed to other products, most notably the 28-kDa peptide (Fig. 1).

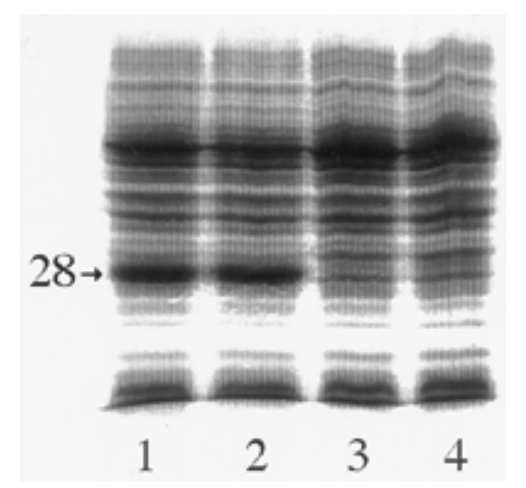

Fig. 2. Detection of the 28-kDa AvrPphB peptide in Escherichia coli. Lanes 1 and 2, extracts of DH5 $\alpha$ (pPPY3034) containing avrPphB cloned for expression in pINK-1; and 3 and 4, DH5 $\alpha$ (pPPY3035) with avrPphB cloned in the opposite orientation. Cultures for lanes 2 and 4 were induced with IPTG. Peptides were separated by SDS-PAGE and visualized with Coomassie blue stain. Note that addition of IPTG caused only a minor increase in yield of the 28 -kDa peptide.

\section{MKIGTQATSLAVLHNQESHAPQAPIAVRPEPAHAIPEIPLDLAIRPRTRGIHPFLAMTLGDK 62 \\ GCASSSGVSLEDDSHTQVSLSDF SVASRDVNHNNICAGLSTEWLVMSSDGDAESRMDHLDY 124 \\ NGEDQSRGSERHQVYNDALRAALSNDDEAPFFTASTAVIEDAGFSLRREPKTVHASGGAQLG 186 \\ QTVAHDVAQSGRKHLLSLRF ANVQGHAIACSCEGSQFKLFDPNLGEFQSSRSAAPQLIKGLI 248 \\ DHYNSLNYDVACVNEFRVS 267}

Fig. 3. Deduced amino acid sequence of AvrPphB. The N-terminal sequence determined for the 28-kDa peptide product isolated from Escherichia coli and used to raise AP1 antiserum is given in bold characters and the peptide used to generate AP2 antiserum is underlined. The major cleavage site was after amino acid 62 (top line). 
Production and isolation of the 28 -kDa peptide.

The complete $a v r P p h B$ ORF was cloned into several vectors for expression in E. coli as a route to purification of the native proteins encoded. Using Coomassie or silver staining it was only possible to detect accumulation of the $28-\mathrm{kDa}$ peptide as shown in Figure 2. Of the vectors tested, pINK-1 gave greatest yields of readily solubilized AvrPphB protein and was used for subsequent purification. The $28-\mathrm{kDa}$ peptide was purified by a sequential combination of ion exchange and size exclusion chromatography. The final product gave a single band after SDS/PAGE gels (Coomassie staining) but some contaminating peptides were detected after silver staining (data not shown). The N-terminal sequence of the $28-\mathrm{kDa}$ peptide was determined from a sample recovered after SDSPAGE. The first nine amino acids were resolved to be GCASSSGVS. This sequence was consistent with the identity of the $28-\mathrm{kDa}$ peptide as the product after cleavage of 62 amino acids from the primary peptide predicted to be encoded by $\operatorname{avrPphB}$ (Fig. 3).

The purified, native, $28-\mathrm{kDa}$ cleavage product isolated from $E$. coli was used to immunize rabbits for generation of polyclonal antibodies and was also tested for its ability to elicit the HR in bean. No macroscopic symptoms developed in bean leaf or pod tissues infiltrated with the peptide. Concentrated preparations applied to the cut surface of highly responsive young pods of cv. Tendergreen $(R 3)$ either in the presence or absence of race 6 of $P$. syringae pv. phaseolicola (which lacks $a v r P h B)$ also failed to cause a response.

\section{Expression of avrPphB is regulated by $h r p L$.}

Polyclonal antibodies raised to the $28-\mathrm{kDa}$ peptide allowed detection of the $35-\mathrm{kDa}$ AvrPphB protein in extracts of both $E$. coli and $P$. syringae pv. phaseolicola. The peptides were produced by race 6 of $P$. syringae pv. phaseolicola containing avrPphB expressed under the direction of the triple lacUV5 promoter in pPPY3031 after bacterial growth in the nutrient rich King's B medium. No AvrPphB protein was detected in race 3 or race 4 (naturally containing $a v r P p h B$ ) grown in King's B or LB broth but expression was induced by growth in minimal medium (Fig. 4). Comparative studies showed that only weak expression occurred in minimal medium alone but

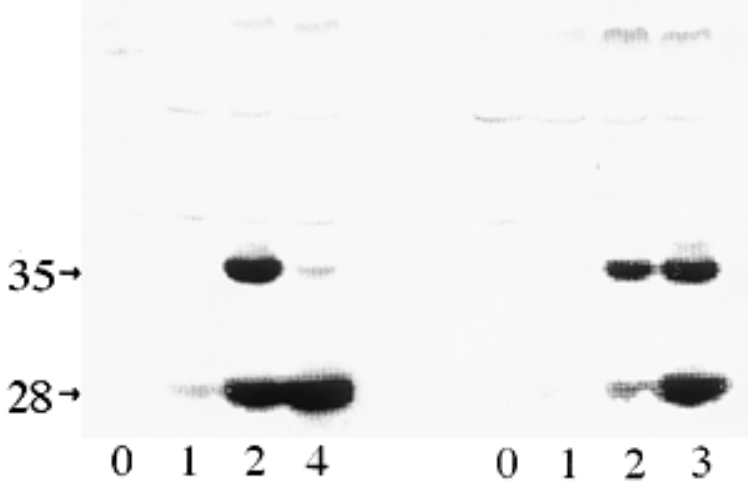

Fig. 4. Western blot of extracts from Pseudomonas syringae pv. phaseolicola race 3 induced in minimal medium $+10 \mathrm{mM}$ sucrose. The blot was probed with AP1 antiserum raised to the $28-\mathrm{kDa}$ peptide. Results are presented from two experiments with induction for $0,1,2,3$, or $4 \mathrm{~h}$. Sizes of the major immunoreactive bands are marked in $\mathrm{kDa}$. the rapid appearance of the proteins was found after addition of sucrose, fructose, and less effectively, glucose. Addition of bean pod tissue did not enhance accumulation of AvrPphB in the presence of sucrose. Under inducing conditions, both the $35-$ and $28-\mathrm{kDa}$ proteins were clearly detected after $2 \mathrm{~h}$. As shown in Figure 4, the relative amounts of the two peptides present varied in repeated experiments. After $18 \mathrm{~h}$ in minimal medium with sucrose, usually only the $28-\mathrm{kDa}$ peptide was detected. The same pattern of processing suggested from expression in $E$. coli was, therefore, also observed in $P$. syringae pv. phaseolicola.

The genomic clone pPPY310 contains avrPphB regulated by its own promoter in pLAFR1 (Jenner et al. 1991). The expression of $a v r P p h B$ from pPPY310 was examined in $h r p L$ and $h r p Y$ mutants of race 6 (Fig. 5). In the hrpL mutant, no production of AvrPphB was observed after growth under inducing conditions with or without added bean tissue. By contrast, mutation in $h r p Y$ did not appear to affect expression of avrPphB. Processing of AvrPphB was observed in the $h r p L$ mutant if protein was expressed from pPPY3031 under the direction of the strong vector promoter (Figure 5). Despite overexpression of AvrPphB in the hrpL mutant, no macroscopic signs of the HR were induced by the transconjugant and only very patchy necrosis in leaves was observed with the $h r p Y^{-}$strain harboring pPPY310 or pPPY3031.

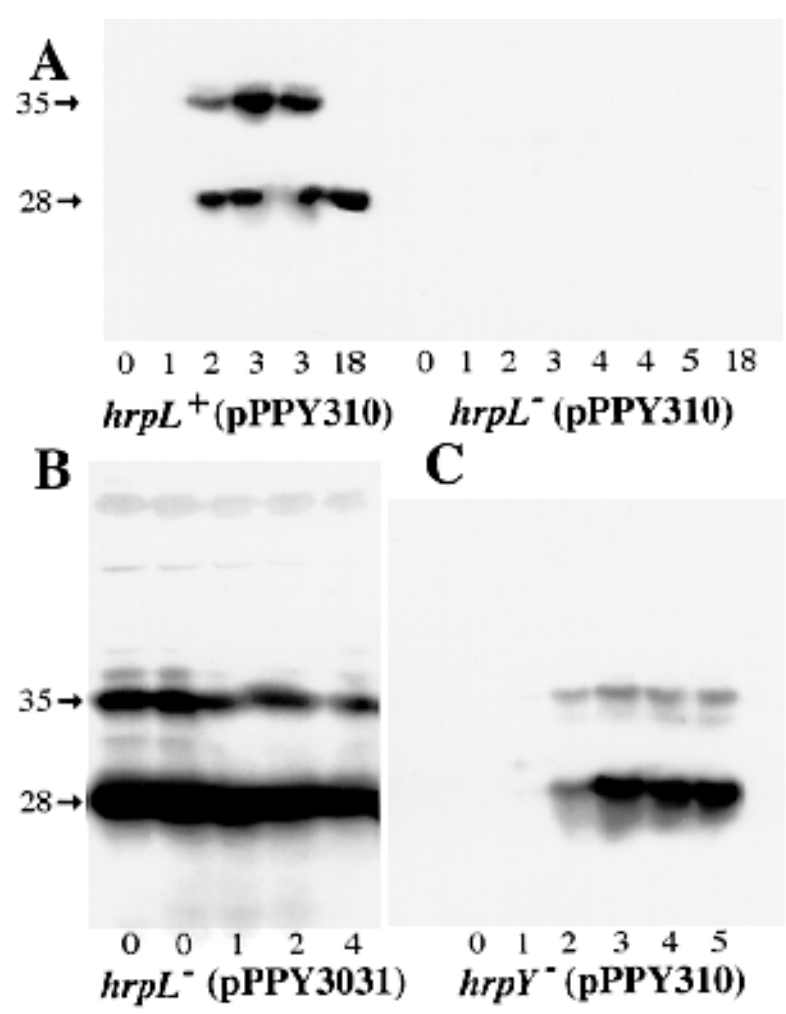

Fig. 5. Production of AvrPphB peptides in Pseudomonas syringae pv. phaseolicola grown under inducing conditions in minimal medium +10 $\mathrm{mM}$ sucrose. A, $h r p L^{+}$, wild-type control race 6 strain with pPPY310 which expresses $a v r P p h B$ from its own promoter, and the same plasmid in a $h r p L$ mutant of race 6 . B, $h r p L$ mutant of race 6 containing pPPY3031 which provides constitutive expression of avrPphB. C, hrpY mutant of race 6 containing pPPY310. Sizes of the major immunoreactive bands are marked in $\mathrm{kDa}$. 


\section{Detection of small peptides derived from AvrPphB and protein localization.}

An oligopeptide, AIRPRTRGIHP selected for predicted antigenicity from the N-terminus of AvrPphB (Fig. 3), was used to generate polyclonal antiserum after its synthesis and conjugation to keyhole limpet haemocyanin. Antibodies produced detected the $35-\mathrm{kDa}$ but not the $28-\mathrm{kDa}$ peptide produced by E. coli (Fig. 6). In P. syringae pv. phaseolicola, the $35-\mathrm{kDa}$ protein was only detected in extracts of bacteria overexpressing AvrPphB from pPPY3031 (data not shown). Modification of SDS PAGE conditions, in particular the use of the method of Schägger and von Jagow (1987) allowed resolution of peptides less than $10 \mathrm{kDa}$ in size following expression of avrPphB. Peptide bands of about $6 \mathrm{kDa}$ were labeled by the anti-peptide antiserum in extracts of both $E$. coli and $P$. syringae pv. phaseolicola. Two small peptides were usually detected in E. coli, whereas several small bands often generating a smear of labeling were seen in extracts of $P$. syringae pv. phaseolicola. As shown in Figure 6, the small peptides increased in concentration during growth under inducing conditions.

The cellular localization of the immunoreactive 35-, 28-, and about 6-kDa peptides was determined in race 3 and race 6 (pPPY3031) grown in both King's B and inducing minimal medium, following cellular fractionation using the method of Young et al. (1994). The peptides were all found in cytoplasmic fractions of lysed bacteria; they were not detected in culture media or in association with the outer membranes. Attempts to localize the proteins by immunocytochemistry were unsuccessful, owing to the low level of labeling found within tissue sections (Ian Brown, unpublished observations).

\section{Expression of AvrPphB and removal of the induction time for development of the HR.}

A characteristic feature of the HR caused by bacteria is the requirement for bacterial protein synthesis to occur during the first few hours after inoculation. Following this period of "induction time," inhibition of protein synthesis by infiltration with antibiotics does not prevent tissue collapse characteristic

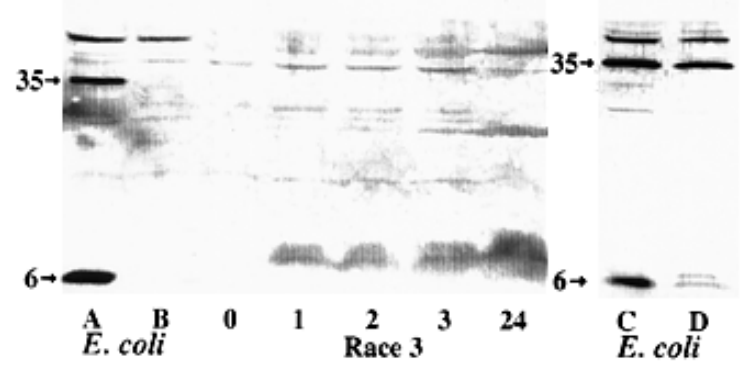

Fig. 6. Western blot analyses of extracts from Escherichia coli and Pseudomonas syringae pv. phaseolicola race 3 probed with antiserum AP2 raised to the peptide synthesized from the $\mathrm{N}$ terminus of the fulllength AvrPphB protein. The first blot shows extracts from Escherichia coli; $\mathbf{A}$, expressing $a v r P p h B$ from pPPY3031 and, B, with the pDSK600 vector alone, and a time course for induction (h) of race 3 in minimal medium $+10 \mathrm{mM}$ sucrose. The second blot was prepared from extracts of E. coli expressing $a v r P p h B$ from C, pPPY3031 and, D, pPPY3034. The sizes of immunoreactive bands are indicated in $\mathrm{kDa}$. Note that, as predicted, the anti-peptide antibodies did not react with the 28-kDa AvrPphB peptide which accumulates in both Escherichia coli and Pseudomonas syringae pv. phaseolicola (see Figs. 1, 2, and 4). of the HR (Klement and Goodman 1967). During the avrPphB/R3 interaction in bean, the induction time is between 2 and 3 h (Harper et al. 1987). We now know that this period coincides with the time required for AvrPphB peptides to be expressed and processed (Fig. 4). A series of experiments was therefore designed to examine the relationship between AvrPphB expression and the induction time. Results obtained are summarized in Table 1. Despite the high yield of AvrPphB peptides from race 6 (pPPY3031) their presence within bacteria was not sufficient to modify the induction time. Thus, race 6 (pPPY3031) grown in King's B gave good yield of the peptides (see Fig. 5) but induction of the HR was still prevented by secondary injection with antibiotics. If race 6 (pPPY3031) or race 3 were grown under inducing conditions the bacteria could be suspended in rifampicin solution prior to injection into bean tissues and the HR was still produced. Growth under $h r p$ and $a v r$ gene inducing conditions therefore removed the requirement for an RNA synthesis-sensitive induction time. Even with induced bacteria, however, a protein synthesissensitive period remained because after injection, a period of 0.5 to $1 \mathrm{~h}$ was still required, during which treatment with streptomycin, kanamycin, or chloramphenicol prevented HR development. Therefore, although the protein synthesis dependent induction time was considerably reduced, it was not completely removed in the $a v r P p h B / R 3$ interaction or the nonhost HR in lettuce.

Since $a v r P p h B$ and $h r p$ genes are regulated by HrpL, we examined the effect on induction times of constitutive expression of $h r p L$ directed by a strong vector promoter. The $h r p L$ ORF was isolated by PCR from DNA of pPPY430 and cloned into pLAFR3 under control of the lac $Z$ promoter to produce pPPY451. The construct, allowing constitutive production of HrpL in Pseudomonas, complemented a $h r p L$ mutation in race 6 strain 1448A::143, restoring full pathogenicity. Vectordirected expression of $h r p L$, although complementing the race 6 hrpL mutant, did not remove its induction time for the HR completely but reduced it by about $1.0 \mathrm{~h}$ in lettuce or (with the addition of pPPY3031 to over-express $a v r P p h B$ ) in bean $\mathrm{cv}$. Tendergreen. Significantly, growth of the transconjugants of the hrp mutant under inducing conditions further reduced the induction times observed, even though only the constitutive level of HrpL would have been present (Table 1).

\section{Delivery of signals for the HR by $E$. coli.}

Despite efficient expression of $a v r P p h B$ with vectors such as pINK-1 and pDSK600, cells of E. coli strains harboring such constructs did not cause the HR after injection into bean cultivars with $R 3$. Various extracts prepared from lysates or sonicates of cells containing high concentrations of the AvrPphB proteins also failed to elicit the HR (Mark H. Bennett, unpublished experiments). However, coordinated expression of the hrp cluster from $P$. syringae pv. phaseolicola and the avirulence genes $a v r P p h B$ and $a v r P p h E$ was found to allow $E$. coli to cause an $R$ gene-specific HR in bean. The genomic clone pPPY430 containing avrPphE also harbors all of the cluster of hrp genes except hrpR (Grimm et al. 1995; Mansfield et al. 1994; Rahme et al. 1991). The first experiments showed that the presence of pPPY430 and pPPY450 (with $h r p L$ expressed from pBluescript) in E. coli strains DH5 $\alpha$ or more effectively in MC4100, allowed induction of the HR in bean genotype A43 and P. acutifolius both of which 
carry $R 2$, but not in other cultivars. Without expression of $h r p L$ from pPPY450 no HR was induced. Introduction of avrPphB on pPPY3031 allowed E. coli strain MC4100 to cause the HR in cv. Tendergreen (R3) in addition to A43 (R2 $+R 3)$. In contrast to the HR phenotypes produced by $P$. syringae pv. phaseolicola, with $E$. coli, the avrPphE/R2 interac-

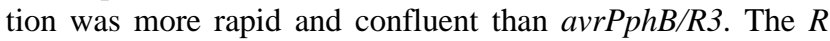
gene-specific nature of the signals delivered by $E$. coli was confirmed by analysis of the reactions of $F_{2}$ progeny of crosses between Canadian Wonder (no $R$ genes) and A43 ( $R 2$ $+R 3+R 4+R 5)$ or Tendergreen $(R 3)$. The $E$. coli strains containing the hrp and avirulence gene constructs caused the HR only in the bean plants which also responded to races of $P$. syringae pv. phaseolicola expressing the avr genes (data not shown). Despite reliable production of the HR in bean, $E$. coli strains expressing $h r p$ and $a v r$ genes did not cause the HR in tobacco leaves, although Harpin was produced from pPPY430 (C. Stevens, unpublished data).

To achieve consistent elicitation of the HR in bean, E. coli had to be grown under well-defined conditions. Optimal activity was achieved if cultures $(20 \mathrm{ml})$ were grown overnight in sealed bottles before induction with IPTG for $2.5 \mathrm{~h}$ prior to inoculation. Phenotypic expression of avrPphE was achieved after induction with IPTG for 1.5 to $3 \mathrm{~h}$ but with $a v r P p h B$, only the $2.5 \mathrm{~h}$ induction gave consistent results. Clearly, induction conditions before injection into the plant had significant effects on the subsequent ability of $E$. coli to deliver the signal for the HR. The requirement for an induction time in the plant was, therefore, also examined. The E. coli cells capable of causing the HR were not affected by injection with rifampicin but an induction time of 0.5 to $1 \mathrm{~h}$ was found using the protein synthesis inhibitors chloramphenicol or kanamycin. As indicated by the results obtained from experiments with $P$. syringae pv. phaseolicola, there was a requirement for protein but not mRNA synthesis by E.coli in the plant. No multiplication of $E$. coli was found during induction of the HR.

\section{DISCUSSION}

We have shown that the AvrPphB protein is processed in three races of $P$. syringae pv. phaseolica; in races 3 and 4 in which $a v r P p h B$ is naturally located on the chromosome and in transconjugants of race 6 , and two strains of E. coli. The major cleavage releases 62 amino acids from the N-terminus. Although the presence of several small bands of about $6 \mathrm{kDa}$ labeled by the antipeptide antibody targeted to the cleaved peptide indicated further processing, the smaller components of AvrPphB all appeared to accumulate within both $P$. syringae pv. phaseolicola and E. coli. After prolonged incubation under inducing conditions, concentration of the full-length 35$\mathrm{kDa} A v r P p h B$ protein was greatly reduced. Analysis of the amino acid sequence of AvrPphB reveals no sites for known protease activity. The significance of processing for function is not known. The HR was caused by both $P$. syringae pv. phaseolicola and E. coli, so the differences between species observed in terms of the stability of the about 6-kDa peptides (Fig. 6) would not appear to be significant. Processing occurred in the absence of hrp gene function regulated by HrpL in $P$. syringae pv. phaseolicola. All of the immunoreactive peptides were found to be cytoplasmic. A similar localization has been reported for two other avirulence gene proteins, AvrBs3 and AvrXa10 from Xanthomonas campestris pv. vesicatoria and $X$. oryzae pv. oryzae, respectively (Brown et al. 1993; Knoop et al. 1991; Young et al. 1995).

Genetic evidence from subcloning and transposon mutagenesis (Jenner et al. 1991) suggests that the entire AvrPphB protein is required for the expression of avirulence.

Table 1. Effect of growth under inducing conditions and directed expression of $h r p L$ and $a v r P p h B$ from strong vector promoters on the induction time for the development of the HR in lettuce and bean

\begin{tabular}{|c|c|c|c|c|c|}
\hline \multirow[b]{3}{*}{ Strain $^{a}$} & \multirow[b]{3}{*}{$\begin{array}{l}\text { Noninduced (N) or } \\
\text { induced }(\mathbf{I})^{\mathbf{b}}\end{array}$} & \multicolumn{4}{|c|}{ Induction time (h) } \\
\hline & & \multicolumn{2}{|c|}{ Lettuce $^{c}$} & \multicolumn{2}{|c|}{ Bean cv. Tendergreen ${ }^{d}$} \\
\hline & & Rifampicin & $\begin{array}{l}\text { Streptomycin } \\
\text { or kanamycin }\end{array}$ & Rifampicin & $\begin{array}{l}\text { Streptomycin } \\
\text { or kanamycin }\end{array}$ \\
\hline \multirow[t]{2}{*}{ Race 6} & $\mathrm{~N}$ & $2.0-3.0$ & $2.0-3.0$ & $-^{f}$ & - \\
\hline & I & 0 & $0.5-1.0$ & - & - \\
\hline \multirow[t]{2}{*}{ Race 6 (pPPY 3031) } & $\mathrm{N}$ & $2.0-3.0$ & $2.0-3.0$ & $2.0-3.0$ & $2.0-3.0$ \\
\hline & I & 0 & $0.5-1.0$ & 0 & $0.5-1.0$ \\
\hline \multirow{2}{*}{$\begin{array}{l}\text { Race } 6(\mathrm{pPPY} 451) \text { or } \\
\text { race6::143(pPPY } 451)\end{array}$} & $\mathrm{N}$ & $1.0-1.5$. & $1.0-1.5$ & - & - \\
\hline & I & 0 & $0.5-1.0$ & - & - \\
\hline \multirow{2}{*}{$\begin{array}{l}\text { Race } 6 \text { (pPPY451, } \\
\text { pPPY3031) }\end{array}$} & $\mathrm{N}$ & $1.0-1.5$ & $1.0-1.5$ & $1.0-1.5$ & $1.0-1.5$ \\
\hline & I & 0 & $0.5-1$ & 0 & $0.5-1.0$ \\
\hline \multirow[t]{2}{*}{ Race $3^{\mathrm{g}}$} & $\mathrm{N}$ & $2.0-3.0$ & $2.0-3.0$ & $2.0-3.0$ & $2.0-3.0$ \\
\hline & I & 0 & $0.5-1.0$ & 0 & $0.5-1.0$ \\
\hline \multirow{5}{*}{\multicolumn{6}{|c|}{$\begin{array}{l}\text { a pPPY3031 over-expresses avrPphB, pPPY } 451 \text { contains } h r p L \text { constitutively expressed from the lac } Z \\
\text { tant of race } 6 \text { strain } 1448 \mathrm{~A} \text {. } \\
\text { b Noninduced, grown overnight on LB; induced, grown for } 3 \mathrm{~h} \text { in minimal medium }+10 \mathrm{mM} \text { sucrose. } \\
{ }^{\mathrm{c}} \text { In lettuce all strains cause a rapid non-host HR. } \\
\text { d Tendergreen contains } R 3 \text { which matches } a v r P p h B \text { in race } 3 \text { or cloned in pPPY } 310 \text { or pPPY } 3031 \text {. } \\
\text { e Kanamycin was used with pPPY3031 as the vector carries streptomycin resistance. } \\
\text { f -, no HR induced. }\end{array}$}} \\
\hline & & & & & \\
\hline & & & & & \\
\hline & & & & & \\
\hline & & & & & \\
\hline \multicolumn{6}{|c|}{${ }^{\mathrm{g}}$ Identical results were obtained with race 6 (pPPY310), i.e., with the cloned $\operatorname{avrPphB}$ gene under con } \\
\hline
\end{tabular}


If we assume that one of the peptides functions as an elicitor, the full-length product may be required to allow correct processing. One or other of the peptides produced may act as a chaperone, allowing transfer of the active peptide via the hrp dependent secretion system. In Yersinia, secretion of YOPs through the contact mediated type III system has been shown to require chaperones, the Ysc proteins (Wattiau et al. 1996). Alignment of the sequences of the AvrPphB peptides with proteins known to act as chaperones failed to reveal significant similarity. An alternative role for AvrPphB protein is as an enzyme, and in this case the $28-\mathrm{kDa}$ peptide may represent the functional product of the $35-\mathrm{kDa}$ apoprotein. Gopalan et al. (1996) have recently reported that the AvrB protein is functional when expressed in planta. Our findings indicate that application of this approach to other avirulence genes may produce misleading results, because the correct processing of the full-length peptide to produce the fraction with elicitor activity may not occur in the plant. It would, nevertheless, be intriguing to determine if all or any of the AvrPphB peptides function as elicitors when expressed in transgenic plants. In this respect $A$. thaliana (with RPS5) may be a more tractable model than $P$. vulgaris for which transformation systems are not fully established (De la Fuente-Martinez et al. 1993).

Regulation of avirulence genes by $h r p L$ has been demonstrated using transcript analysis and reporter gene fusions for several avr genes (Dangl 1994). We have confirmed regulation of $a v r P p h B$ by analysis of the encoded protein. The AvrPphB protein was produced in a $h r p Y$ mutant but this strain caused only a very weak HR in cv. Tendergreen $(R 3)$. Even if AvrPphB was over-expressed in the hrpL mutant, no HR was produced. Our results therefore support the proposal that $h r p Y$ and other $h r p$ genes, many of which appear to be regulated by HrpL as discussed by Xiao et al. (1994), have a role in delivery of signals to the plant.

Failure of hrp mutants to multiply in the plant could be used as an explanation for failure to deliver elicitors of the HR. $E$. coli also fails to multiply, but has now been shown to be able to cause the $R$ gene-specific HR determined in bean by both avrPphB and avrPphE. Our findings with the avirulence and hrp genes from $P$. syringae pv. phaseolicola cloned on pPPY430 are in close agreement with the phenotypic expression of avirulence genes in E. coli reported by Pirhonen et al. (1996). The important difference is that the earlier work used pHIR11 which includes all of the hrp genes and hrmA from $P$. syringae pv. syringae (Huang et al. 1988; Heu and Hutcheson 1993). Our clone, pPPY430, lacks hrpR and, in it, avrPphE effectively replaces $h r m A$ at the left border of the hrp cluster. Clearly neither hrmA nor hrpR is required for E. coli to express the avirulence phenotype in bean. The requirement for $h r p R$ may be overcome by the directed expression of the similarly regulatory gene $h r p L$. It may be significant that the HR was not induced by our constructs in tobacco, although Harpin (He et al. 1993) was produced. It is possible that hrmA may act as an avirulence gene in tobacco.

In their seminal article, Huynh et al. (1989) first described the removal of the induction time (as determined by rifampicin injection) by growing bacteria under conditions which induced expression of $h r p$ and $a v r$ genes. We have confirmed their findings using the $R$ gene-specific HR in cv. Tendergreen and non-host HR in lettuce. Although the rifampicin (mRNA synthesis) sensitive induction time was completely removed, protein synthesis inhibitors always defined a short induction period for development of the HR. Irrespective of growth under inducing conditions, the requirement for a brief period of protein synthesis in the plant was found not only for $P$. syringae pv. phaseolicola but also E. coli. A simple explanation for our results is that bacteria have to construct a secretory apparatus that allows delivery of elicitors of the HR. Support for this proposal comes from the recent finding that the HrpA protein from the $h r p Z$ operon in $P$. syringae pv. tomato DC3000 is a component of a pilus-like structure formed under inducing conditions (Elina Roine, unpublished results). Following contact between bacteria and plant cells, secretory channels may be constructed which allow delivery of pathogenicity and virulence determinants across the plant cell wall and into the plant cell. Such a system would suggest further analogy with enteric bacteria pathogenic to animals in which type III protein secretion systems have been associated with filamentous structures and the injection of proteins into animal cells (Parsot et al. 1995; Rosquist et al. 1994).

To examine the role of $h r p L$ in controlling the HR caused by $P$. syringae pv. phaseolicola we constructed pPPY451 to achieve constitutive expression directed by the lac $Z$ promoter in pLAFR3. The failure of pPPY451 to remove induction times completely in transconjugants of wild-type race 6 suggested that perhaps additional HrpL protein was required and produced from the chromosomal hrpL regulated by its own promoter. However, the hrpL mutant of race 6, 1448A::143, was complemented by pPPY451 but the transconjugant, although pathogenic, had also not lost its induction time completely (Table 1). Intriguingly, growth of 1448A::143 (pPPY451) under inducing conditions unexpectedly allowed further reduction in the induction time. Since the only source of the regulatory HrpL protein in 1448A::143 was via constitutive expression from pPPY451, these results suggest that there are regulators in addition to $h r p L$ directly involved in the control of genes allowing phenotypic expression of the HR in $P$. syringae pv. phaseolicola. The identification of the pathogenicity determinants which are not regulated by $h r p L$ merits further study.

\section{METHODS}

\section{Bacteria and plasmids.}

Principal bacterial strains, cosmids, and plasmids used are listed in Table 2. Isolates and transconjugants of $P$. syringae pv. phaseolicola were grown routinely on King's medium B (KB) agar at $25^{\circ} \mathrm{C}$ and Escherichia coli strains on LuriaBertani (LB) agar or in LB broth at $37^{\circ} \mathrm{C}$ (King et al. 1954; Miller 1972). Antibiotics, obtained from Sigma, were usually used at the following concentrations $(\mu \mathrm{g} / \mathrm{ml})$; ampicillin, Ap (50); chloramphenicol, $\mathrm{Cm}$ (25); kanamycin, $\mathrm{Km} \mathrm{(25);}$ nalidixic acid, Nal (50); rifampicin, Rif (50); spectinomycin, Sp (50); streptomycin, Sm (100); tetracycline, Tc (15). Plasmids were mobilized into $P$. syringae pv. phaseolicola and $E$. coli MC4100 by triparental mating. Transformation was also used to introduce plasmids into the other more tractable strains of E. coli.

\section{Plants and pathogenicity tests.}

Leaves and pods of cultivars of French bean (Phaseolus vulgaris L.) and tepary bean ( $P$. acutifolius L.) were inocu- 
lated as previously described (Harper et al. 1987). Leaves of lettuce cv. Diana and tobacco plants cv. White Burley, were also infiltrated with bacterial suspensions using a syringe and hypodermic needle and incubated at $24^{\circ} \mathrm{C}$ (Bestwick et al. $1995)$. To examine growth of $E$. coli in leaves, tissue was dissected from inoculation sites, homogenized in $10 \mathrm{mM} \mathrm{MgCl}_{2}$ and serial dilutions of the homogenate were spread onto $\mathrm{LB}$ agar with appropriate antibiotics to allow colony development at $37^{\circ} \mathrm{C}$.

\section{Purification of $A v r P p h B$ peptide and production of antisera.}

Cultures of DH5 $\alpha$ (pPPY3034) were grown at $25^{\circ} \mathrm{C}$ overnight to an $\mathrm{OD}_{600}$ of 0.5 in LB following induction with isopropyl- $\beta$-D-thiogalactopyranoside (IPTG) $(1 \mathrm{mM})$. Cells were lysed by sonication and the supernatant (10-ml sample) dialyzed for $4 \mathrm{~h}$ at $4^{\circ} \mathrm{C}$ against 1 liter of $20 \mathrm{mM}$ bis-tris propane (BTP, $\mathrm{pH}$ 8.0). After filtration (0.22- $\mu \mathrm{m}$ membrane), 2-ml samples were applied to an ion exchange Mono Q column on a Pharmacia FPLC system and eluted with $20 \mathrm{mM}$ BTP $\pm 1 \mathrm{M}$ $\mathrm{NaCl}$. Proteins recovered were analyzed by SDS-PAGE and fractions rich in the $28-\mathrm{kDa}$ AvrPphB peptide combined, concentrated by ultrafiltration (Diaflo membrane, Amicon, cut off $10-\mathrm{kDa}$ ) and applied to a size exclusion Superose 12 column which was eluted with phosphate-buffered saline at $\mathrm{pH}$ 7.3. Fractions containing AvrPphB were again collected and reapplied to the Superose 12 column. In total about $0.5 \mathrm{mg}$ of purified protein were recovered. After SDS PAGE of the puri- fied product, about $2 \mu \mathrm{g}$ was transferred by electroblotting to PVDF membrane for N-terminal amino acid sequencing carried out using an Applied Biosystems 477A sequencer by Margaret Pickering, Royal Holloway and Bedford New College, Egham, Surrey.

Antiserum AP1 to the native $28-\mathrm{kDa}$ protein was raised in New Zealand White rabbits using standard immunization protocols, titers were assessed by ELISA before terminal bleeds were recovered. Antisera were depleted against total protein extracts from $E$. coli DH5 $\alpha$ (pDSK600 or pPPY3035). Antipeptide antibodies (AP2), were raised using the Genosys custom-peptide antisera facility (Genosys Biotechnologies Inc. Cambridge, U.K.). In Western blots, antisera to the 28$\mathrm{kDa}$ protein and small peptide were usually used at 1:4,000 and 1:1,000 dilution, respectively.

\section{Protein analysis and immunoblotting.}

Production of AvrPphB was examined in P. syringae pv. phaseolicola and in E. coli containing various expression vectors. Protein synthesis was also induced in $P$. syringae pv. phaseolicola using slight modifications of the conditions described by Innes et al. (1993). Bacterial cultures, usually 200 $\mathrm{ml}$, were grown in $\mathrm{LB}$ at $25^{\circ} \mathrm{C}$, shaking, to an $\mathrm{OD}_{600}$ of 0.5 to 0.7. Cells were washed with $10 \mathrm{mM} \mathrm{MgCl}$ at $25^{\circ} \mathrm{C}$ and then resuspended in minimal medium $(13 \mathrm{mM}$ potassium phosphate buffer, pH 5.5, $17 \mathrm{mM} \mathrm{NaCl}, 30 \mathrm{mM}\left(\mathrm{NH}_{4}\right)_{2} \mathrm{SO}_{4}, 2.8$ $\mathrm{mM} \mathrm{Mg} \mathrm{SO}$ ) supplemented with various carbon sources at 10 $\mathrm{mM}$ and continued to be incubated at $25^{\circ} \mathrm{C}$. Aliquots $(40 \mathrm{ml})$

Table 2. Bacterial strains and plasmids used in this study ${ }^{\mathrm{a}}$

\begin{tabular}{|c|c|c|}
\hline Strain & Relevant properties & Source or reference \\
\hline \multicolumn{3}{|l|}{ Bacteria } \\
\hline \multicolumn{3}{|c|}{ Pseudomonas syringae pv. phaseolicola } \\
\hline \multicolumn{3}{|c|}{ Wild- type strains } \\
\hline $1301 \mathrm{~A}$ & Race 3 & Jenner et al. 1991 \\
\hline $1302 \mathrm{~A}$ & Race 4 & \\
\hline 1448AR & Race 6 Rif $^{\mathrm{R}}$ from $1448 \mathrm{~A}$ & Fillingham et al. 1992 \\
\hline 1448AN & Race $6 \mathrm{Nal}^{\mathrm{R}}$ from $1448 \mathrm{~A}$ & Fillingham et al. 1992 \\
\hline \multicolumn{2}{|c|}{ hrp mutants derived from $\mathrm{Tn} 3$-gus insertions } & Mansfield et al. 1994 \\
\hline $1448 \mathrm{~A}:: 143$ & hrpL mutant of race 6 & \\
\hline 1448A::148 & $\operatorname{hrp} Y$ mutant of race 6 & \\
\hline \multicolumn{3}{|l|}{ Escherichia coli } \\
\hline DH5 $\alpha$ & $\mathrm{Nal}^{\mathrm{R}}$, recA, lacZ $\Delta M 15$ & Bethesda Research Labs \\
\hline MC4100 & 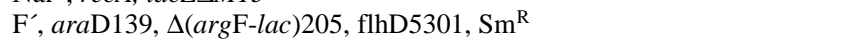 & Casadaban 1976 \\
\hline HB101 & recA, $\mathrm{Sm}^{\mathrm{R}}$ & Boyer and Roulland-Dussoix 1969 \\
\hline \multicolumn{3}{|c|}{ Vectors and helper plasmid } \\
\hline pBluescriptII SK ${ }^{+}$ & $\mathrm{Ap}^{\mathrm{R}}$, ColE1 replicon, multiple cloning and priming sites & Stratagene \\
\hline pLAFR3 & $\mathrm{Tc}^{\mathrm{R}}$, IncP1 replicon, $\mathrm{Tra}^{-}, \mathrm{Mob}^{+}$, lacZ promoter, cosmid & Staskawicz et al. 1987 \\
\hline pDSK600 & $\mathrm{Sp}^{\mathrm{R}}$, IncQ replicon, 3x lac UV5 promoter & Murillo et al. 1994 \\
\hline pINK-1 & Expression vector, $1 p p$ and $l a c$ promoters & Keen and Tamaki 1986 \\
\hline pGP1-2 & P15A replicon, T7 RNA polymerase production & Tabor and Richardson 1985 \\
\hline pT7-5 & T7 polymerase promoter & \\
\hline pRK2013 & $\mathrm{Km}^{\mathrm{R}}$, ColE1 replicon, $\mathrm{Tra}^{+}, \mathrm{Mob}^{+}$, helper plasmid & Figurski and Helinski 1979 \\
\hline \multicolumn{3}{|c|}{ Clones containing the avirulence gene $\operatorname{avrPph} B$} \\
\hline pPPY310 & pLAFR1 based genomic clone & Jenner et al. 1991 \\
\hline pPPY3031 & 2-kb $P v u I I$ fragment cloned for expression of $a v r P p h B$ in pDSK600 & N. T. Keen \\
\hline pPPY3030 & As pPPY3031 but insert cloned in the opposite orientation & N. T. Keen \\
\hline pPPY3034 & 2-kb BamHI-KpnI fragment cloned for expression of $a v r P p h B$ in pINK-1 & N. T. Keen \\
\hline pPPY3035 & As pPPY3034 but insert cloned in the opposite orientation & N. T. Keen \\
\hline pT7-51 & 1.6-kb $B g l \mathrm{II}-\mathrm{Cla \textrm {I }}$ fragment containing $a v r P p h B$ cloned in pT7-5 & This work \\
\hline \multicolumn{3}{|l|}{ Additional plasmids } \\
\hline pPPY430 & pLAFR3-based clone from race 4 containing $h r p$ genes and $a v r P p h E$ & Mansfield et al. 1994 \\
\hline pPPY450 & hrpL ORF cloned in pBluescript & This work \\
\hline pPPY451 & hrpL ORF cloned in pLAFR3 & This work \\
\hline
\end{tabular}

${ }^{a} \mathrm{Nal}^{\mathrm{R}}, \mathrm{Rif}^{\mathrm{R}}, \mathrm{Sm}^{\mathrm{R}}, \mathrm{Ap}^{\mathrm{R}}, \mathrm{Km}^{\mathrm{R}}, \mathrm{Tc}^{\mathrm{R}}, \mathrm{Sp}^{\mathrm{R}}$ indicate resistance to nalidixic acid, rifampicin, streptomycin, ampicillin, kanamycin, tetracycline, and spectinomycin, respectively. 
were removed from the culture at intervals, the bacteria pelleted and stored at $-20^{\circ} \mathrm{C}$ until further processing.

The bacterial pellets were thawed and then resuspended in 1 $\mathrm{ml}$ of extraction buffer $(50 \mathrm{mM}$ Tris, $100 \mathrm{mM} \mathrm{NaCl}, 1 \mathrm{mM}$ DTT, 1 mM EDTA, 1 mM PMSF, 5\% glycerol, pH 8.0), sonicated on maximum power using a Soniprep 150 sonicator for $30 \mathrm{~s}$, centrifuged at $16,000 \times g$ at $4^{\circ} \mathrm{C}$ for $30 \mathrm{~min}$ and the supernatants collected, aliquoted, flash frozen in liquid nitrogen, and stored at $-20^{\circ} \mathrm{C}$. The total protein concentration of each extract was established using the Bradford method. To examine the localization of AvrPphB, 500-ml cultures were grown in King's B or induced in minimal medium $+10 \mathrm{mM}$ sucrose and the method of Young et al. (1994) used for fractionation, except that cells of $P$. syringae pv. phaseolicola were ruptured by three cycles of sonication.

Samples usually representing $100 \mu \mathrm{g}$ of total protein were resuspended in Laemmli buffer, boiled for $4 \mathrm{~min}$ and analyzed by SDS-PAGE using 10 or $15 \%$ acrylamide (Bjerrum et al. 1986; Laemmli 1970). Tricine-SDS PAGE was used to resolve peptides of less than $10 \mathrm{kDa}$ (Schägger and von Jagow 1987). Proteins were stained with Coomassie Blue R250 or transferred to nitrocellulose or PVDF membranes by electroblotting. Western blots were reacted with antisera and bound antibody visualized after incubation with alkaline-phosphatase coupled anti-rabbit immunoglobulin (Sigma) and color development with nitroblue tetrazolium and 5-bromo-4-chloroindoyl phosphate.

\section{Labeling AvrPphB in E. coli.}

The T7 RNA polymerase-based system was used essentially as described by Tabor and Richardson (1985) to label proteins with $\left[{ }^{35} \mathrm{~S}\right]$-methionine. E. coli HB101(pT7-51, pGP1-2) was grown in LB (Amp, $40 ; \mathrm{Km}, 40 \mu \mathrm{g} / \mathrm{ml}$ ) at $30^{\circ} \mathrm{C}$ until midexponential phase $\left(\mathrm{OD}_{600}, 0.5\right) ; 0.2 \mathrm{ml}$ of the culture was centrifuged for $1 \mathrm{~min}$ and pelleted cells were washed twice with M9 medium (Miller 1972). The pellet was resuspended in 1 $\mathrm{ml}$ of M9 medium supplemented with $20 \mu \mathrm{g} / \mathrm{ml}$ thiamine and $0.01 \%$, w/v, 19 amino acids (minus methionine). Bacteria were grown with shaking at $30^{\circ} \mathrm{C}$ for an hour and then the temperature was shifted to $42^{\circ} \mathrm{C}$ for $15 \mathrm{~min}$. Rifampicin was added to a final concentration of $200 \mu \mathrm{g} / \mathrm{ml}$ and allowed to penetrate the cells at $42^{\circ} \mathrm{C}$ for a further $10 \mathrm{~min}$ and then the cells were returned to $30^{\circ} \mathrm{C}$ for $20 \mathrm{~min}$. One microliter of $\left[{ }^{35} \mathrm{~S}\right]$ methionine $(10 \mu \mathrm{Ci}$, Amersham) was added to the cells at $30^{\circ} \mathrm{C}$ and after incubation, cells were recovered by centrifugation. All traces of supernatant were removed from the pellet before resuspension in $100 \mu \mathrm{l}$ of cracking buffer $(60 \mathrm{mM}$ Tris.HCl, pH 6.8, 1\% SDS, 1\% 2-mercaptoethanol, 10\% glycerol, $0.01 \%$ bromophenol blue). Samples were heated to $95^{\circ} \mathrm{C}$ for 3 to $5 \mathrm{~min}$ and stored at $-20^{\circ} \mathrm{C}$ until needed, all $100 \mu \mathrm{l}$ was loaded per gel track for SDS-PAGE. Gels were dried and exposed to Kodak film for autoradiography.

\section{Induction conditions to allow $E$. coli to induce the HR.}

A 30-ml McCartney bottle containing $20 \mathrm{ml}$ of LB was inoculated with $10 \mu \mathrm{l}$ of $20 \%$ glycerol stock of the E. coli strain (at an $\mathrm{OD}_{600 \mathrm{~nm}}$ of 0.5 ). Strong antibiotic selection was applied (Ap, 120; Tc, 25 and for pPPY3031, Sp at $75 \mu \mathrm{g} / \mathrm{ml}$ ). The bottle was sealed tightly and incubated overnight $(19 \mathrm{~h})$ at $37^{\circ} \mathrm{C}$ with shaking at $150 \mathrm{rpm}$ to give an $\mathrm{OD}_{600}$ of 0.5 . The bacteria were pelleted, resuspended in $10 \mathrm{ml}$ of fresh LB containing antibiotics and $1 \mathrm{mM}$ IPTG and grown at $30^{\circ} \mathrm{C}$ with shaking for $2.5 \mathrm{~h}$. Aliquots $(1.5 \mathrm{ml})$ of the final suspension were centrifuged and bacteria resuspended in $10 \mathrm{mM} \mathrm{MgCl}_{2}$ for inoculation. The concentration used for inoculation was usually $3 \times 10^{8}$ cells $/ \mathrm{ml}$.

\section{Determination of the induction time.}

Sites in leaves inoculated with bacterial suspensions were marked with a waterproof marker. At 0.5 -h intervals the same site was injected with antibiotic solution. To ensure complete inactivation of bacteria to prevent the HR, higher concentrations of antibiotics were used than added to media, i.e. Sm, 400; Rif, 250; Kan, 200 and Cm, $200 \mu \mathrm{g} / \mathrm{ml}$. Bacteria were also suspended in antibiotics prior to injection to test their requirement for an induction time in the plant.

\section{PCR and cloning.}

Standard techniques for DNA manipulation were used for cloning into various vectors (Sambrook et al. 1989). The ORF of $h r p L$ was recovered from pPPY430 by PCR using primers; forward, 5'-GAATTCATGAGGAGGAGGTAAGCCCATGTTTCCGAA-3' and reverse, 5'-GAATTCTCAGGCGAACGGGTCAATCT-3' allowing recovery of the complete coding sequence from $P$. syringae pv. phaseolicola (Mansfield et al. 1994) with the upstream sequence modified in an attempt to improve the efficiency of the ribosome binding site in E. coli. The PCR product was purified using a spun column (S-300 HR, Pharmacia) digested with EcoRI and ligated to pBluescript vector to produce pPPY450. The ORF was excised from pPPY450 and cloned into the EcoRI site in pLAFR3 to allow expression to be directed from the lac $Z$ promoter in this vector within $P$. syringae pv. phaseolicola.

\section{ACKNOWLEDGMENTS}

This research was supported by a grant from the UK Biotechnology and Biological Sciences Research Council. We wish to thank Noel Keen and colleagues for vectors and constructs, and Conrad Stevens for invaluable discussions.

\section{LITERATURE CITED}

Bestwick, C. S., Bennett, M. H., and Mansfield, J. W. 1995. Hrp mutant of Pseudomonas syringae pv. phaseolicola induces cell wall alterations but not membrane damage leading to the HR in lettuce (Lactuca sativa). Plant Physiol. 108: 503-516.

Bjerrum, Q. J., and Schafer-Nielsen. 1986. Buffer systems and other transfer parameters for semi-dry electroblotting with a horizontal apparatus. Pages 315-327 in: Electrophoresis '86 M. J. Dunn, ed. VCH, Weinheim, Germany.

Bonas, U. 1994. hrp genes of phytopathogenic bacteria. Pages 79-98 in: Bacterial Pathogenesis of Plants and Animals: Molecular and Cellular Mechanisms. Curr. Top. Microbiol. Immunol. Vol. 192; J. L. Dangl, ed. Springer-Verlag, Berlin, Heidelberg.

Boyer, H. W., and Roulland-Dussoix, D. 1969. A complementation analysis of the restriction and modification of DNA in Escherichia coli. J. Mol. Biol. 41:459-472.

Brown, I. R., Mansfield, J. W., Irlam, I., Conrads-Strauch, J., and Bonas, U. 1993. Ultrastructure of interactions between Xanthomonas campestris pv. vesicatoria and pepper, including immunocytochemical localization of extracellular polysaccharides and the AvrBs3 protein. Mol. Plant-Microbe Interact 6:376-386.

Casadaban, M. J. 1976. Transposititon and fusion of the lac genes to selected promoters in Escherichia coli using bacteriophage lambda and Mu. J. Mol. Biol. 104:541-555.

Dangl, J. L. 1994. The enigmatic avirulence genes of phytopthogenic 
bacteria. Pages 99-118 in: Molecular and Cellular Mechanisms. Curr. Top. Microbiol. Immunol. Vol. 192. Bacterial Pathogenesis of Plants and Animals. J. L. Dangl, ed. Springer-Verlag, Berlin, Heidelberg.

Dangl, J., Ritter, C., Gibbon, M., Mur, L. A. J., Wood, J. R., Goss, S., Mansfield, J., Taylor, J. D., and Vivian, A. 1992. Functional homologs of the Arabidopsis Rpml disease resistance gene in bean and pea. Plant Cell 4:1359-1369.

De la Fuente-Martinez, J. M., Mosqueda-Cano, G., Alvarez-Morales, A., and Herrera-Estrella, L. 1993. Pathogen-derived strategy to produce transgenic plants resistant to the bacterial toxin phaseolin. Pages 579586 in: Advances in Molecular Genetics of Plant-Microbe Interactions. Vol. 2. E. W. Nester and D. P. S. Verma, eds. Kluwer Academic Publishers, Dordrecht.

Figurski, D. H., and Helinski, D. R. 1979. Replication of an origincontaining derivative of plasmid RK2 dependent on a plasmid function provided in trans. Proc. Natl. Acad. Sci. USA 76:1648-1652.

Fillingham, A. J., Wood, J., Bevan, J. R., Crute, I. R., Mansfield, J. W., Taylor, J. D., and Vivian, A. 1992. Avirulence genes from Pseudomonas syringae pathovars phaseolicola and pisi confer specificity toward both host and non-host species. Physiol. Mol. Plant Pathol. 40:115.

Gopalan, S. Bauer, D. W., Alfano, J. R., Loniello, A. O., He, S. Y., and Collmer, A. 1996. Expression of the Pseudomonas syringae avirulence gene protein AvrB in plant cells alleviates its dependence on the hypersensitive response and pathogenicity (Hrp) secretion system in eliciting genotype-specific hypersensitive cell death. Plant Cell 8:1095-1105.

Grant, M. R., Godiard, L., Straube, E., Ashfield, T., Lewald, J., Sattlier, A., Innes, R. W., and Dangl, J. L. 1995. Structure of the Arabidopsis $R P M I$ gene enabling dual specificity disease resistance. Science 269:1543.

Grimm, C., Aufsatz, W., and Panopoulos, J. N. 1995. The hrpRS locus of Pseudomonas syringae pv. phaseolicola constitutes a complex regulatory unit. Mol. Microbiol. 15:155-165.

Harper, S., Zewdie, N., Brown, I. R., and Mansfield, J. W. 1987. Histological, physiological and genetical studies of the responses of leaves and pods of Phaseolus vulgaris to three races of Pseudomonas syringae pv. phaseolicola and to Pseudomonas syringae pv. coronafaciens. Physiol. Mol. Plant Pathol. 31:153-172.

Heu, S., and Hutcheson, S. W. 1993. Nucleotide sequence and properties of the hrmA locus associated with the P. syringae pv. syringae $61 \mathrm{hrp}$ gene cluster. Mol. Plant-Microbe Interact. 6:553-564.

He, S. Y., Huang, H. C., and Collmer, A. 1993. Pseudomonas syringae pv. syringae Harpin $_{\mathrm{Pss}}$ : A protein that is secreted via the Hrp pathway and elicits the hypersensitive response in plants. Cell 73:1-20.

Huang, H. C., Lin, R. H., Chang, C. J., Collmer, A., and Deng, W. L. 1995. The complete hrp gene cluster of Pseudomonas syringae pv. syringae 61 includes two blocks of genes required for Harpin ${ }_{\mathrm{Pss}}$ secretion that are arranged colinearly with Yersinia ysc homologs. Mol. Plant-Microbe Interact. 8:733-746.

Huang, H. C., Schuurink, R., Denny, T. P., Atkinson, M. M., Baker, C. J., Yucel, I., Hutcheson, S. W., and Collmer, A. 1988. Molecular cloning of a Pseudomonas syringae pv. syringae gene cluster that enables Pseudomonas fluorescens to elicit the hypersensitive response in tobacco. J. Bacteriol. 170:4748-4756.

Huynh, T., Dahlbeck, D., and Staskawicz, B. J. 1989. Bacterial blight of soybean: Regulation of a pathogen gene determining host cultivar specificity. Science 245:1374-1377.

Innes, R. W., Bent, A. F., Kunkel, B. N., Bisgrove, S. R., and Staskawicz, B. J. 1993. Molecular analysis of avirulence gene avrRpt2 and identification of a putative regulatory sequence common to all known Pseudomonas syringae avirulence genes. J. Bacteriol. 175:4859-4869.

Jenner, C., Hitchin, E., Mansfield, J., Walters, K., Betteridge, P., and Taylor, J. 1991. Gene-for-gene interactions between Pseudomonas syringae pv. phaseolicola and Phaseolus. Mol. Plant-Microbe Interact. 4:553-562.

Keen, N. T. 1992. The molecular biology of disease resistance. Plant Mol. Biol. 19:109-122.

Keen, N. T., and Tamaki, S. 1986. Structure of two pectate lyase genes from Erwinia chrysanthemi EC16 and their high level expression in Escherichia coli. J. Bacteriol. 168:595-606.

Keen, N. T., Tamaki, S., Kobayashi, D., Gerhold, D., Stayton, M., Shen, H., Gold, S., Lorang, J., Thordal-Christensen, H., Dahlbeck, D., and
Staskawicz, B. 1990. Bacteria expressing avirulence gene D produce a specific elicitor of the soybean hypersensitive reaction. Mol. PlantMicrobe Interact. 3:112-121.

King, E. O., Ward, M. K., and Raney, D. E. 1954. Two simple media for the demonstration of pyocyanin and flurescin. J. Lab. Clin. Med. 44:301-307.

Klement, Z., and Goodman, R. N. 1967. The role of the living cell and induction time in the hypersensitive reaction of the tobacco plant. Phytopathology 57:322-323.

Knoop, V., Staskawicz, B., and Bonas, U. 1991. Expression of the avirulence gene avrBs 3 from Xanthomonas campestris pv. vesicatoria is not under the control of $h r p$ genes and is independent of plant factors. J. Bacteriol. 173: 7142-7150.

Laemmli, U. K. 1970. Cleavage of structural proteins during the assembly of the head of bacteriophage T4. Nature 227:680-685.

Lorang, J., Shen, H., Kobayashi, D., Cooksey, D., and Keen, N. T. 1994. avrA and avrE in Pseudomonas syringae pv. tomato PT23 play a role in virulence on tomato plants. Mol. Plant-Microbe Interact. 7:508515.

Mansfield, J., Jenner, C., Hockenhull, R., Bennett, M., and Stewart, R. 1994. Characterization of avrPphE, a gene for cultivar specific avirulence from Pseudomonas syringae pv. phaseolicola which is physically linked to $h r p Y$, a new $h r p$ gene identified in the halo-blight bacterium. Mol. Plant-Microbe Interact. 7:726-739.

Mansfield, J., Tsiamis, G., Puri, N., Bennett, M., Jenner, C., Stevens, C, Teverson, D., Lyons N., and Taylor, J. Analysis of gene-for-gene interactions between Pseudomonas syringae pv. phaseolicola and Phaseolus. In: Pseudomonas syringae Pathovars and Related Pathogens. K. Rudolph, T. J. Burr, J. W. Mansfield, D. Stead, A. Vivian, and J. Von Kietzell, eds. Kluwer Academic Publishers, Dordrecht, The Netherlands. In press.

Midlands, S. L., Keen, N. T., Sims, J. J., Midland, M. M., Stayton, M M., Burton, V., Smith, M. J., Mazzola, E. P., Graham, J. K., and Clardy, J. 1993. The structure of syringolides 1 and 2, novel Cglycosidic elicitors from Pseudomonas syringae pv. tomato. J. Org. Chem. 58:2940-2945.

Miller, J. H. 1972. Experiments in Molecular Genetics. Cold Spring Harbor Laboratory, Cold Spring Harbor, New York.

Murillo, J., Shen, H., Gerhold, D., Sharma, A., Cooksey, D. A., and Keen, N. T. 1994. Characterization of pPT23B, the plasmid involved in syringolide production by Pseudomonas syringae pv. tomato PT23. Plasmid 31:275-287.

Parsot, C., Menard, R., Gounon, P., and Sansonetti, P. J. 1995. Enhanced secretion through the Shigella flexneri Mxi-spa translocon leads to assembly of extracellular proteins into macromolecular structures. Mol. Microbiol. 16:291-300.

Pirhonen, M. U., Lidell, M. C., Rowley, D. L., Lee, S. W., Jin, S., Liang, Y., Silverstone, S., Keen, N. T., and Hutcheson, S. W. 1996. Phenotypic expression of Pseudomonas syringae avr genes in E. coli is linked to the activities of the hrp-encoded secretion system. Mol. Plant-Microbe Interact. 9:252-260.

Rahme, L. G., Mindrinos, M. N., and Panopoulos, N. J. 1991. Genetic and transcriptional organization of the hrp cluster of Pseudomonas syringae pv. phaseoliocla. J. Bacteriol. 173:575-586.

Ritter, C., and Dangl, J. L. 1995. The avrRpm1 gene from Pseudomonas syringae pv. maculicola is required for virulence on Arabidopsis. Mol. Plant-Microbe Interact. 8:444-453.

Rosqvist, R., Magnusson, K. E., and Wolf-Watz, H. 1994. Target cell contact triggers expression and polarized transfer of Yersinia YopE cytotoxin into mammalian cells. EMBO J. 13:964-972.

Sambrook, J., T., Fritsch, E. F., and Maniatis, T. A. 1989. Molecular Cloning : A Laboratory Manual. 2nd ed. Cold Spring Harbor Laboratory, New York.

Schägger, H., and von Jagow, C. 1987. Tricine-sodium dodecyl sulphate-polyacylamide gel electrophoresis for the separation of proteins in the range of 1 to 100-kDa. Anal. Biochem. 166:368-379.

Simonich, M. T., and Innes, R. W. 1995. A disease resistance gene in Arabidopsis with specificity for the avrPph3 gene of Pseudomonas syringae pv. phaseolicola. Mol. Plant-Microbe Interact. 8:637-640.

Smith, M. J., Mazzola, E. P., Sims, J. J., Midland, S. L., Keen, N. T., Burton, V., and Stayton, M. M. 1993. The syringolides: Bacterial Cglycosyl lipids that trigger plant disease resistance. Tetrahedron Lett. 34:223-226.

Staskawicz, B., Dahlbeck, D., Keen, N., and Napoli, C. 1987. Molecular 
characterization of cloned avirulence genes from race 0 and race 1 of Pseudomonas syringae pv. glycinea. J. Bacteriol. 169:5789-5794.

Tabor, S., and Richardson, C. C. 1985. A bacteriophage T7 RNA polymerase-promoter system for controlled exclusive expression of specific genes. Proc. Natl. Acad. Sci. USA. 82:1074-1078.

VanGijsegem, F., Gough, C., Zischek, C., Niqueux, E., Ariat, M., Genin, S., Barberis, P., German, S., Castello, P., and Boucher, C. 1995. The hrp gene locus of Pseudomonas solanacearum, which controls the production of a type III secretion system, encodes eight proteins related to components of the bacterial flagellar biogenesis complex. Mol. Microbiol. 15:1095-1114.

Vivian, A., Gibbon, M. J., and Murillo, J. 1997. The molecular genetics of specificity determinants in plant pathogenic bacteria. Pages 293328 in: The Gene-for-Gene Relationship in Host-Parasite Interactions., I. R. Crute, J. J. Burden, and E. B. Holub eds, C. A. B. International, U. K.
Vivian, A., and Mansfield, J. 1993. A proposal for a uniform genetic nomenclature for avirulence genes in phytopathogenic pseudomonads. Mol. Plant-Microbe Interact. 6:9-10.

Wattiau, P., Woestyn, S., and Cornelis, G. R. 1996. Customized secretion chaperones in pathogenic bacteria. Mol. Microbiol. 20:255-262.

Xiao, Y., Heu, S., Yi, J., Lu, Y., and Hutcheson, S. W. 1994. Identification of a putative alternative sigma factor and characterization of a multicomponent regulatory cascade controlling the expression of Pseudomonas syringae pv. syringae Pss61 hrp and hrmA genes. J. Bacteriol. 176:1025-1036.

Xiao, Y., Lu, Y., Heu, S., and Hutcheson, S. W. 1992. Organization and environmental regulation of the Pseudomonas syringae pv. syringae $61 \mathrm{hrp}$ cluster. J. Bacteriol. 174:1734-1741.

Young, S. A., White, F. F., Hopkins, C. M., and Leach, J. E. 1994. AvrXa10 protein is in the cytoplasm of Xanthomonas oryzae pv. oryzae. Mol. Plant-Microbe Interact. 7: 799-804. 